\title{
The Impact of E-Baking Service Quality Dimensions on Customers' Satisfaction and Brand Equity (Case Study: Refah Bank, Tehran)
}

\author{
Asadollah kordnaeij ${ }^{1}$, Ph. D, Hossein Askaripoor ${ }^{2}$, MA \& Abbas Imani ${ }^{3}$, M.A \\ ${ }^{1}$ Associated Professor in Management, Tarbiat Modares University, Tehran, Iran \\ 2 Department of Management, Chabahar Maritime University, Chabahar, Iran \\ ${ }^{3}$ Department of Management, Tarbiat Modares University, Tehran, Iran \\ Correspondence: Asadollah kordnaeij, Ph. D, Associated Professor in Management, Tarbiat Modares University, \\ Tehran, Iran. E-mail: naeij@modares.ac.ir
}

Received: August 25, 2013

Accepted: October 31, 2013

Online Published: November 5, 2013

doi:10.5430/bmr.v2n4p25

URL: http://dx.doi.org/10.5430/bmr.v2n4p25

\begin{abstract}
Present study is conducted to evaluate and identify the most important e-baking service quality Dimensions in Iranian banking industry which would finally yield to more customers' satisfaction and Brand Equity. To this end, Refah bank is used for this study. The research is a survey - type. To collect data, a questionnaire was used that was a combination of different resources in the relevant literature. A sample consisting of 384 customers of the bank in Tehran was selected. Structural Equation Model (SEM) and Confirmatory Factor Analysis (CFA) as well as two LISREL and SPSS software packages were used to analyze data. Research findings indicate significant impact of "Accessibility", "Easiness", "Trust", "Security", "Website designing", "Website content", "Speed" and "Commission" on "Satisfaction" and the significant impact of "Satisfaction" on "Brand Equity".
\end{abstract}

Keywords: E-baking, Service quality Dimensions, Satisfaction, Brand Equity and Refah Bank

\section{Introduction}

Today, financial services are confronting with rapid changes in technology, unstable economic environment, intensive competition, different and changing climate and an imbalance ambience which all create a set of important challenges in the industry (Yuksel et al., 2010; White \& Nteli, 2004). Financial service sector especially banks are facing with experiences not seen in their history. Such changes have huge impacts on both the structure of the industry and competition nature (Jiyoung et al., 2009) and current situation of global economy has led into unexpected challenges for any banker. It is not surprising that in such a turbulent environment with increasingly changes, financial institutes are enforced to change their reactions to the market so that they should concentrate less on products and more on customers and relations and they should pursue a short rather than a long term perspective (Harrison, 2008). Today, Internet is emerged as a competitive arena for future financial services which enables the banks to provide their customers with more traits and lower costs than traditional banking (Han \& Baek., 2004). As a result, one can see mitigating, structural and technological changes in global banking system toward a more integrated banking environment. By providing diverse advantages and competitive services as well as restructuring their services, banks are looking for using the technology rapidly and to meet the needs of their customers through internet banking (Ma, Zhengwei, 2012). E-banking is a new type of banking which represents banking services in any time and location in online environments through creating facilities to increase the velocity and efficiency of services (Khan et al., 2009; Lee, 2009). In e-banking, customer interacts with bank's website. To this end, high quality of internet services is too vital for bank. Since e-banking - in contrary to traditional banking - involves in nonhuman interactions between customers and bank's information system, key factors in the success of e-banking are customer's satisfaction, attracting and retaining (Khan et al., 2009). As mentioned before, the initial aim of any organization especially a bank is to focus on customers' satisfaction. Authors have found that customer's satisfaction is an influential part in running a successful business and almost no business can survive without its customers' satisfaction (Yuksel et al., 2010). Authors' emphasis on the importance of customers' satisfaction in banking industry and its role in different ways of keeping the customers are not negligible (Farquhar and Panther, 2008). Service quality plays a vital role in the cusses of any bank especially in generating competitive advantage and increasing competitive power. Looking for service quality in all organizations particularly in banks is a correct initiative since financial services are similar to intangible 
services (Rod et al., 2009). According to Parasuraman and Cronin Taylor, quality service is the introduction of customers' services which cause that customers feel satisfaction or dissatisfaction. On the other hand, service quality has a positive relationship with keeping the customers (Friman \& Edvardsson, 2003). There are too many banks and a standard should be set for their satisfied performance. The importance of customers' satisfaction and service quality in supporting the development of banking communications is specially emphasized in banking literature (Petridou et al., 2007). Bank managers know that customers' satisfaction from service quality is the source of a competitive advantage and bank profitability (Amoah-Mensah \& Aborampah, 2010). As a result, there is no doubt on the importance of customers' satisfaction and service quality is the ultimate target of service providers. However, customers' satisfaction is not sufficient today and companies should not be only pleased customers' satisfaction. They should be assured that satisfied customers are also loyal. Today, marketing art is that the customers of an organization are colleagues inside the organization and are supporters outside it. In the meantime, customers' commitment has found a special position (Luis et al, 2008). Therefore, companies attempt to establish long term relations with customers to create their loyalty and to improve profitability and Brand Equity. In recent decades, improving long term, profitable and successful relation for both sides is paid attention by authors (Anansuperlu, 2009).

Below, some researches on e-banking in recent years are summarized in table 1.

Table 1. some researches on E-banking in recent years

\begin{tabular}{llll}
\hline Research & Authors & Findings & Year \\
\hline $\begin{array}{l}\text { Customer's conception } \\
\text { certain factors: the basis to }\end{array}$ & $\begin{array}{l}\text { Yousafzai } \\
\text { accept e-banking }\end{array}$ & $\begin{array}{l}\text { The findings indicate that some certain factors are important } \\
\text { in predicting customer's behavior such as the readiness to }\end{array}$ & $\begin{array}{l}\text { accept technology, age average, gender, beliefs and intent. } \\
\text { Trust and e-commerce: studies }\end{array}$ \\
Brian et al. & More trust by people to e-commerce, more tendencies to & 2003
\end{tabular}

on customer's conception

Identifying affecting factors on Chinese customers' satisfaction from e-banking

Ma, Zhengwei.

reuse it. Conceived market attitude, site quality, technical trust and job experience are the factors which impact on customer's trust.

Present study aims at identifying affecting factors on customers" satisfaction as well as the relationship between customers' satisfaction and website quality. The findings indicate that website desired quality impacts on customers' satisfaction directly and positively and affecting factors on customers' satisfaction from e-banking are efficiency, security, information, easy usage and website content.

$\begin{array}{ll}\text { Customers' } & \text { loyalty in Srini et al. } \\ \text { e-commerce: } & \text { studying the }\end{array}$ records and results
Customer service quality in Greece banking industry

The role of satisfaction and the capability of using the website in customers' loyalty development and verbal propaganda in online banking services

The role of retailing quality in online satisfaction and trust

Arasli et Customers' satisfaction of provided services by banks al. impacts on verbal propaganda directly and positively.

Luis et al. Satisfaction along with mutual impact by the capability of using website has a positive effect on customers' loyalty and verbal propaganda. Likewise, the capability of using website impacts positively on customer satisfaction and loyalty is significantly depended to positive verbal propaganda.

Jiyoung et Online satisfaction impacts on the process of online loyalty al. and there is a significant relationship between online satisfaction and online trust. Website designing impacts positively on satisfaction and security also impacts positively on online trust.

The role of conceived usability, Carlos et As the user conceives and satisfies from system usability, satisfaction and trust on loyalty al. his/her trust s increased and, as a result, more loyalty will to website create toward the website. 


\section{E-Baking Service Quality Dimensions}

Overall, 9 affecting factors on customers' satisfaction were determined after studying the literature and background of present paper as explained below:

\subsection{Accessibility}

Accessibility is defined as the capability of users to acquire information and services of the website which is depended to many factors such as size and format of materials, users' hardware/software, internet connection, spatial conditions and users' strengths/weaknesses (Hackett \& Parmanto, 2009). One of the advantages of websites is accessibility to information centers while responsiveness and full time availability are, inter alia, the most important traits of online banking (Yang et al., 2004).

H1: Accessibility Impacts on Customers' Satisfaction Positively.

\subsection{Easiness}

In information system literature, easiness of application is considered as an affecting factor on customer satisfaction (Swaid \& Wigand, 2007; Yoon, 2010). In a simple definition, one can say that easiness of application in online banking is the comfort of using online services such as internet banking, telephone banking, mobile bank, ATMs, etc. (Misic et al., 1999; Yoon, 2010). In other word, the amount someone believes that using a certain system in terms of physical or mental efforts and learning does not require paramount attempts (Vainio, 2006). E-banking provides more easiness and enables the customers to access internet banking in all the times and locations which are considered as a relative advantage (Gerrard \& Cunningham, 2003). More easiness would provide better understanding of website contents and applications so that it can play a vital role in developing customer's effective behaviors such as satisfaction, loyalty and positive verbal advertising in e-banking (Luis et al., 2008). It depends on different dimensions such website structure, integration, readability, searching facilities, easy learning on system management for user, easy memorization of basic operation, efficiency of site designing, the percentage of decreasing the errors and user's overall satisfaction (Cho \& Park, 2001; Wirtz \& Chew, 2002).

H2: Easiness Impacts on Customers' Satisfaction Positively.

\subsection{Trust}

Distrust impacts negatively on users' tendency to do internet financial exchanges while customers are yet doubted about trusting to e-banking (Gerrard \& Cunningham, 2003). Concerning e-banking and e-commerce, trust is defined as: "believing that service providers or sellers attempt to meet the expectations of the people and to avoid opportunistic behaviors" (Gu et al., 2009). In fact, trust is a kind of mental mood which relates the intent with vulnerability of acceptance from expectations from intents or behaviors of other people (kassim, 2009). Many researches have indicated that trust has a positive relationship with technology acceptance and when someone trusts a bank, he/she is more tended to use its internet services (Gu, et al., 2009). Trust is considered as a technology acceptance model when it has a remarkable impact on users' tendency to perform internet financial exchanges (Wang et al., 2003).

H3: Trust Impacts on Customers' Satisfaction Positively.

\subsection{Security}

Often, websites gather a diverse set of users'/customers' information. To the same reason, security is considered as an important concern ( $\mathrm{Lin} \& \mathrm{Wu}, 2002$ ). Security if referred to a degree by which the website guarantees the security of financial and personal information of customers (Mohd Khalaf Ahmad et al., 2011). Despite of technological advancements in internet security such coding, digital signature certification and online carbon copies, customers are yet concerned on financial exchanges security as one of the most important functions of e-banking (Ranganathan \& Ganapathy, 2002). There are various studies on security as one of the most important indicators of internet banking and all have emphasized that the security of internet banking impacts positively on the satisfaction of customers (Jun \& cai, 2001; liao \& cheung, 2008).

H4: Security Impacts on Customers' Satisfaction Positively.

\subsection{Website designing}

In terms of human - computer interactions, the type of website designing is highly important and impacts intensively on users' performance (palmer, 2002). In the meantime, Ranganathan \& Ganapathy believe that website designing plays a vital role in attracting, retaining and improving customers' interests in website (Yoon, 2010). Website designing aims at an attractive and enjoyable appearance (Mohd Khalaf Ahmed et al., 2011). More studies on internet service quality have especially focus on website designing and all authors agree that websites should be designed in a 
manner to enhance customers' conception on website and its services (Loiacono et al., 2002). Furthermore, desired website designing would increase accessibility and plays a critical role in its attractiveness (Ranganathan \& Ganapathy, 2002). One of the best ways to improve website designing is that customers should be asked to evaluate it (Liu \& Arnett, 2000). Various studies are conducted on website designing and authors have confirmed the effectiveness of website designing on customers' satisfaction (Liu et al., 2008; Zviran et al, 2006).

H5: Website Designing Impacts on Customers' Satisfaction Positively.

\subsection{Website content}

In online banking, website content is one of the most important factors impacts on e-banking (Mohd Khalaf Ahmad et al., 2011). In fact, it points out the desirability of website information in customers' viewpoints. Content impacts on customers' behavior. Hence, many studies consider information content as a benchmark of website quality (Yoon, 2010). Websites should provide profitable information on the type of provided services for facilitating users' better conception (La \& Kandampully, 2002; Cho \& Park, 2001). Furthermore, users need to have supplementary information on banks, recommendations by experts, financial reports, relevant links and contact information such as address and telephone number(s) (Van Riel et al, 2001). Overall, content profitability depends on value, confidence and correct information (Yanga, 2005).

H6: Website Content Impacts on Customers' Satisfaction Positively.

\subsection{Speed}

The speed of operations and rapid responsiveness has always attracted the attentions and it is a main concern of information systems and e-commerce (DeLone \& McLean, 1992; Srinivasan, 1985). Likewise, there is a significant relationship between the speed of downloading and users' satisfaction. Download speed depends on the content of materials, computing hardware and connection method (Ma, Zhengwei, 2010). Speed which refers to the duration of response is highly considered in information systems and e-commerce due to increase of focusing on the efficiency of operational resources. In advanced societies, users are sensitive to the speed of services. Therefore, speed and time saving are two vital considerations (Swaid \& Wigand, 2007; Yoon, 2010; Liao \& Cheung, 2002). Hence, they are considered as important factors in users' satisfaction and one of the main measures to evaluate websites (Aldawani \& Palvia, 2002). Liao and Cheung say that in advances societies, customers are more sensitive to the speed of received services. Therefore, speed is a factor to prevent time wasting and as a radical consideration to attract the satisfaction of customers from internet banking services.

H7: Speed Impacts on Customers' Satisfaction Positively.

\subsection{Commission}

Providing qualitative banking services along with proper costs and commissions always lead into customers' satisfaction and, as a result, they are considered as main concerns of bank managers (Gerlach, 2000; Jun and Cai, 2001). In the meantime, taking lower commissions in banking industry is considered as a relative advantage. Various studies show that successful banks ask lower commissions against their services and taking high commissions often challenge their successes (Devlin, 1995; Siriluck \& Speece, 2003). On way to achieve this aim is that internet banking mitigates operational and official costs successfully and saving the relevant costs helps the banks to lower or even eliminate their commissions (Mohd Khalaf Ahmad et al., 2011).

H8: Commission Impacts on Customers' Satisfaction Positively.

\section{Satisfaction}

Customer's satisfaction is a mood or reaction by consumer/customer to buy and consume a product. In marketing terms, customer's satisfaction is woven with the experience of buying the goods or services. When the outcomes are evaluated by customers, they are in turn comparing the results of their own experiences with expected results (Lee \& Chung, 2009). In other words, customer's satisfaction is a degree of positive feeling of customer to service provider (Deng, et al., 2010). According to Oliver, customer's satisfaction is a response to consumer's prosperity and answering this radical question that whether the product/service has provided an enjoyable level of consumption related prosperity or not (Jamal \& Naser, 2002). Customer's satisfaction is a mode by which the customer feels that product specifications are in accordance to his/her expectations. Lingenfield believes that customer's satisfaction is a feeling in psychological terms that is the result of comparing the products with customers' needs and demands as well as social expectations from the products. Reviewing authors' viewpoints on satisfaction definition indicates that there are three main factors in all definitions which can shape a basis for a comprehensive definition on satisfaction: 
1. Customer's satisfaction is in fact a (emotional or rational) response.

2. This response is emphasizing on a certain case (expectations, merchandises, services, etc.).

3. This response happens in a certain time (after consumption, after purchase decision, after receiving services, etc.) (Xu et al., 2009, Pratten, 2004).

H9: Customers' Satisfaction Impacts on Brand Equity Positively.

\section{Brand Equity and Its Aspects}

Marketing thinkers have provided varied definitions on the concept of brand equity. Some have defined it as a set of assets or debts related to a brand, name or symbol that reduces the value represented by a product or service to customers or add to it. Some have introduced it as a distinguished impact of brand knowledge on consumer's response to brand marketing. Others have considered brand equity as a power that brand may acquire through name, symbol or logo. However, the simplest definition on brand equity is an added value or the reward of a products to a customer attributed to brand (Yoo et al, 2000; He et al, 2011). If a customer believes that there are remarkable differences among brands and it leads into an important part of information in purchase decision, his/her reliance to brand - based decision making would increase. Brands especially those ones that have very high value are considered as the most valuable and powerful assets of the organization.

Brand equity is seen in both marketing literature and financial literature. In present study, by brand equity we mean "customer - based brand equity" in marketing literature. Customer - based brand equity views to brand value generating resources in customers' view. Thus, brand power is hidden in what customers have learnt, felt, seen or heard overtime regarding their experiences toward brand. Brand generates value for customer and companies and the main resource of such value is hidden in customers and their mindsets that would determine the real value for organization's stakeholders. Aaker (1991) believes that customer - based brand equity consists of four aspects: "brand perceived quality", "brand awareness", "brand association" and "brand loyalty". Awareness refers to individuals' capability to identify a name and trademark which provides a certain category of product. Brand perception originates from various conceptions of consumers to brand in their minds. Quality shows the quality of products and services provided by the brand. Brand loyalty is shaped by positive conceptions and feelings toward brand which leads into purchase repetition (Martinez et al., 2005). Below, each aspect of brand equity by Aaker is described.

\subsection{Perceived quality:}

brand perceived quality is the judgment by consumer on the excellence or superiority of a product (service) based on its aim compared to other products (services) in the market which may be or not be compatible with product real quality.

\subsection{Brand awareness:}

it is understood by brand recognition and reminding it. In fact, brand awareness is a potential capability to determine and recall that brand is defined as a member of a certain category of a product.

\subsection{Brand association:}

includes everything that relates customer mind to brand. Such association can be related to product, certain geographical location, company, rivals, retailers, shop, symbol, design or lifestyle. According to Aaker (1991), brand associations are set of brand assets and debts and include communications between brand consumers' minds, brand association is one of the most important aspects of brand equity (Lee \& Beck, 2008).

\subsection{Brand loyalty:}

brand loyalty is a relative biased behavioral reaction in purchase by a person to brand overtime which leads into a certain propensity to that brand in decision making and evaluation process (Chaudhuri \& Holbrook, 2001). Such reaction is a function of individual's psychological and mental processes. Customers' loyalty to brand causes positive word of mouth Advertising, fundamental barriers on rivals' entry, more capability of the company in responding to rivals' threats, more sales and income and customers' lower sensitivity to rivals' marketing efforts. Huge number of loyal customers to a brand is considered as an asset for the company and it is recognized as the main indicator of brand equity (Sahin et al., 2011).

In the view of researchers, Customer's satisfaction from E-banking services impacts on brand equity.

Based on the background, literature and hypotheses of the research, the provided model in present study can be drawn as seen in figure 1. 


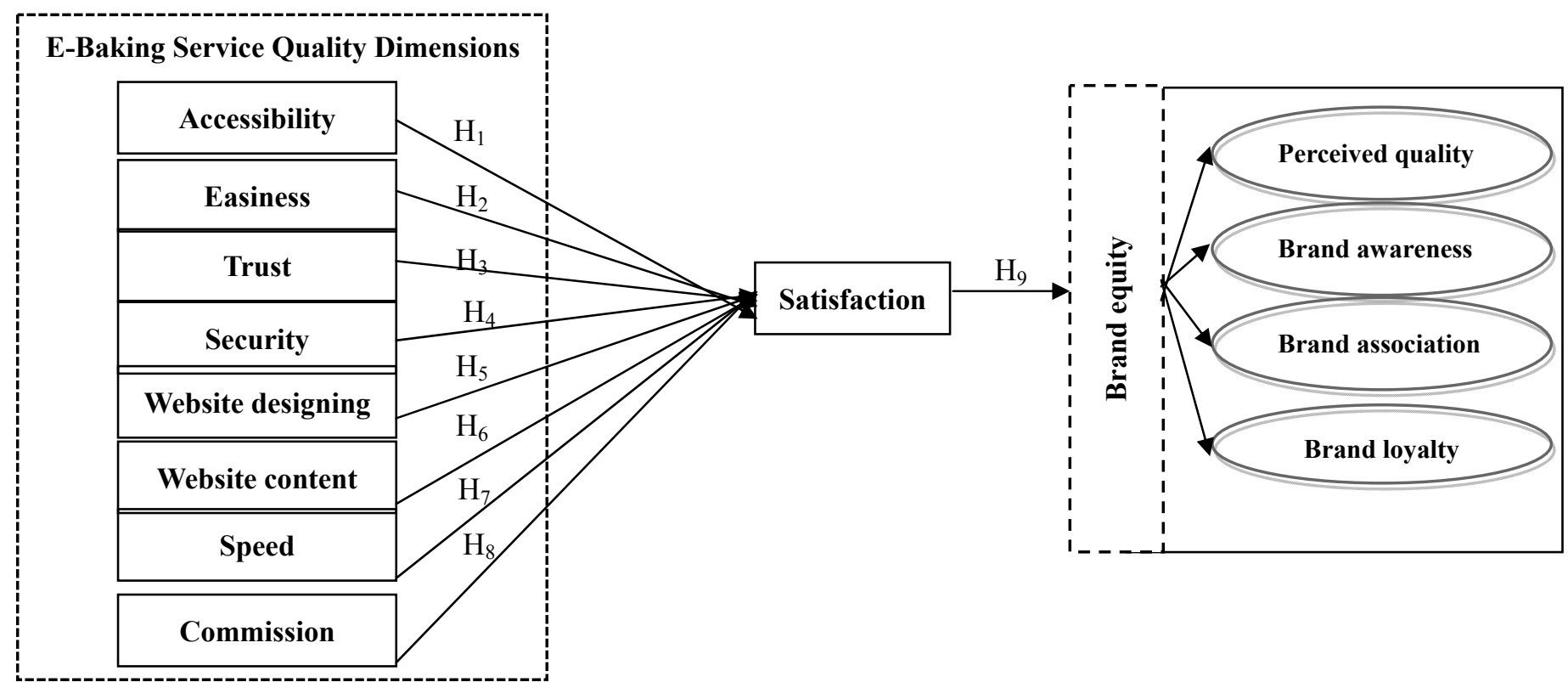

Figure 1. Conceptual Model

References: Ma, 2012; Yoon \& Kim, 2009; Rod et al., 2009; Aaker et al., 2001; Mohd Khalaf Ahmad et al., 2011

\section{Methodology}

\subsection{Research methodology}

In terms of aim and the nature of studied problem, the present study is an applied research, it is a survey in terms of data collection method and finally, it is descriptive one in terms of its methodology. A questionnaire is used to collect data. Questionnaire items are based on Liker five - range scale (completely disagree, disagree, relatively agree, agree, completely agree) and they were distributed among respondents personally.

\subsection{Measures}

Present study consists of ten variables including "Accessibility", "Easiness", "Trust", "Security", "Website designing", "Website content", "Speed", "Commission", "Satisfaction" and "Brand Equity". All variables are measured by a set of measurements. To measure "Accessibility" 2 items developed by Yoon \& Kim, (2009), 3 items for "Easiness", 2 items for "Security" and 2 items for "Trust" developed by Suh \& han (2009), 2 items for "Website designing", 4 items for "Website content" and 3 items for "Speed" developed by Aladwani \& Palvia (2002) and Yoon \& Kim, (2009), 2 items for "Commission" developed by Mohd Khalaf Ahmad et al. (2011), 3 items for "Satisfaction" developed by Rod et al (2009) and 10 items for "Brand Equity" developed by Boyl et al. (2011) and Aaker's (1991) were used. On this basis, the questionnaire consists of 33 items shown in table 2. Several demographical items were mentioned at the end of the questionnaire explained in research findings section.

\subsection{Data analysis method}

In present study, Structural Equation Modeling (SEM) test is used to analyze data and research hypotheses. SEM is a very strong multivariable analysis from multivariable regression family which helps the author to test a set of regression equations simultaneously. To study the reliability and validity of the questionnaire, Cronbach's alpha ratio and variance average index are used. To measure the fitness of provided model, Confirmatory Factor Analysis (CFA) is applied.

\subsection{Research Statistical sample and community}

The present research aims at evaluating and identifying the most important e-baking service Dimensions to achieve customers' satisfaction and improve profitability and Brand Equity in Iranian banking industry. To this end, as a successful domestic bank, Refah Bank was selected for present study. Thus, research population consists of all internet service customers of Refah Bank in Tehran. Since research population is indefinite, sample volume was computed as 384 by Kokaran formula. To achieve the sufficient respondents and more randomizing of sampling method, the authors attended in different branches of the Refah bank severally and distributed the questionnaires randomly. To keep a safe edge, 400 questionnaires were distributed of which 384 ones were confirmed.

\subsection{Questionnaire Reliability and Validity}

To analyze the internal structure of the questionnaire and to determine the validity, the results form CFA and AVE are used. To this end, standard factor loading and AVE index for all items and variables were computed as shown in table 2. Validity is established when standard factor loading for each variable is measured and AVE index for each main variable is greater than 0.5 (Fornell \& Larcker, 1981). As seen in table 2, standard factor loading and AVE 
index are greater than 0.5 for all items and variables. Therefore, one can conclude that the questionnaire enjoys acceptable validity. To measure reliability, Cronbach's $\alpha$ value is used. To establish reliability, Cronbach's $\alpha$ value should be greater than 0.7 in order to be accepted. Cronbach's $\alpha$ values for all constructs are shown in table 2 and all of them are greater than 0.7 .

Table 2. the Weights of Standard Factor Loading, Cronbach's Alpha and AVE

\begin{tabular}{|c|c|c|c|}
\hline Items & SFL & $\begin{array}{l}\text { Cronbach's } \\
\alpha \text { Value }\end{array}$ & AVE \\
\hline Accessibility & & 0.77 & 0.57 \\
\hline Accessibility to Refah Bank's Portal is easy for me. & 0.61 & & \\
\hline Refah Bank's website uploads with high speed. & 0.53 & & \\
\hline Easiness & & 0.75 & 0.53 \\
\hline Refah Bank's website can be navigated and used easily. & 0.58 & & \\
\hline Refah Bank's website and its services are searchable easily. & 0.54 & & \\
\hline Refah Bank's website is user - friend. & 0.62 & & \\
\hline Security & & 0.72 & 0.51 \\
\hline Refah Bank's website security system protects my personal data. & 0.55 & & \\
\hline $\begin{array}{l}\text { Refah Bank's website doses not disseminate customers' personal and confidential } \\
\text { information to third parties. }\end{array}$ & 0.59 & & \\
\hline Website designing & & 0.83 & 0.54 \\
\hline Design of Refah Bank's website is beautiful. & 0.56 & & \\
\hline Design of Refah Bank's website is attractive. & 0.65 & & \\
\hline Website content & & 0.79 & 0.58 \\
\hline Refah Bank website provides updated and on-time information. & 0.61 & & \\
\hline The content of Refah Bank's website is easily understandable. & 0.53 & & \\
\hline The reports in Refah Bank's website are complete and they provide a proper level of details. & 0.51 & & \\
\hline Refah Bank’s website provides you with valuable and distinguished information. & 0.56 & & \\
\hline Speed & & 0.76 & 0.52 \\
\hline The speed of connecting to Refah Bank's website is ideal & 0.63 & & \\
\hline The speed of financial operation in Refah Bank is acceptable. & 0.69 & & \\
\hline The speed of uploading in Refah Bank's website is ideal. & 0.56 & & \\
\hline Commission & & 0.81 & 0.62 \\
\hline I believe that the commission of provided services by Refah Bank is fair. & 0.59 & & \\
\hline The commission of provided services by Refah Bank is lower than other banks. & 0.62 & & \\
\hline Trust & & 0.74 & 0.53 \\
\hline Problems of Refah Bank website are minimum. & 0.57 & & \\
\hline Refah Bank website provides promised services. & 0.57 & & \\
\hline Satisfaction & & 0.86 & 0.60 \\
\hline I feel satisfied of financial transaction through Refah Bank's website. & 0.58 & & \\
\hline I feel satisfied of provided services by Refah Bank’s website. & 0.54 & & \\
\hline Overall, I feel satisfied of Refah Bank's website functions. & 0.65 & & \\
\hline Loyalty & & 0.88 & 0.60 \\
\hline I suggest using Refah Bank website to others. & 0.53 & & \\
\hline I always use the services provided by Refah Bank website. & 0.57 & & \\
\hline $\begin{array}{l}\text { I believe that services provided by Refah Bank website are in accordance with my } \\
\text { expectations. }\end{array}$ & 0.61 & & \\
\hline Brand equity & & 0.84 & 0.62 \\
\hline Refah Bank website supplies very high quality products & 0.53 & & \\
\hline Refah Bank website provides trustable services & 0.49 & & \\
\hline Refah Bank website provides services with excellent characteristics & 0.56 & & \\
\hline When I think about E-banking, Refah Bank is one of the brands comes to my mind & 0.63 & & \\
\hline Refah Bank website is one I recognize it well & 0.57 & & \\
\hline I can distinguish Refah Bank website from other websites & 0.56 & & \\
\hline Always, I have a good experience in using Refah Bank website & 0.53 & & \\
\hline I remember the Refah Bank website attractive advertising & 0.51 & & \\
\hline Upon hearing the name of E-banking, I remember its logo in my mind & 0.54 & & \\
\hline I am loyal to Refah Bank & 0.59 & & \\
\hline Total & & 0.78 & \\
\hline
\end{tabular}




\section{Findings}

\subsection{Research descriptive findings}

To recognize the nature of studied community better and more familiarity with research variables, it is necessary to describe such data before analyzing them. As mentioned, 374 respondents were studied in present research of which 139 were male and 245 were female. Additionally, 222 were less than 25 - year - old, 130 were between 25 and 40 years old and 32 were above 40 - year - old. In terms of education, 35 were less than diploma, 145 had diploma, 88 had associate of arts, and 28 had masters and higher degrees. The results are depicted in table 3.

Table 3. Research Demographic Variables

\begin{tabular}{|c|c|c|c|c|}
\hline Variable & Age domain & Quantity & $\%$ & Aggregative Percentage \\
\hline \multirow[t]{2}{*}{ Gender } & Male & 139 & 36.19 & 36.19 \\
\hline & Female & 245 & 65.81 & 100 \\
\hline \multirow[t]{3}{*}{ Age } & -25 & 222 & 57.81 & 57.81 \\
\hline & $25-40$ & 130 & 33.85 & 91.66 \\
\hline & +40 & 32 & 8.34 & 100 \\
\hline \multirow[t]{5}{*}{ Education } & under diploma & 35 & 9.11 & 9.11 \\
\hline & Diploma & 145 & 37.76 & 46.87 \\
\hline & Associate of Arts & 88 & 22.91 & 69.78 \\
\hline & Bachelor & 88 & 22.91 & 92.69 \\
\hline & Masters and higher & 28 & 7.31 & 100 \\
\hline
\end{tabular}

\subsection{Model fitness test}

To determine provided model fitness by CFA, various goodness of fit indicators are used as shown in table 4. Overall, each acquired indicator for model is not itself the reason of fit or unfit of the model; rather, such indicators should be described along with each other. Both $\chi^{2}$ and secondary fitness tests show that the model is adequately proper and they move toward the factors of the model and we focus on such factors. Table 4 indicates the most important indices and depicts that the model enjoy proper fitness. All indices indicate that the model is fit to observed data. Model fit indices show the appropriateness of measuring model since Chi 2 ratio on freedom degree is less than 3, RMSEA is less than 0.9 and other indices are also plausible. In other words, the overall model is significant and admirable.

Table 4. Model Goodness For Fit

\begin{tabular}{rrr}
\hline Index & Ratio & Allowed level \\
& & \\
\hline$\chi^{2} / \mathrm{df}$ & 2.38 & $>3$ \\
GFI & 0.94 & $<0.9$ \\
RMSEA & 0.077 & $>0.9$ \\
CFI & 0.94 & $>0.8$ \\
AGFI & 0.84 & $>0.9$ \\
NFI & 0.93 & $>0.9$ \\
NNFI & 0.96 & \\
\hline
\end{tabular}

\subsection{Testing model hypotheses}

Initially, Pearson correlation ratio test was used to study the relations between the variables of each hypothesis. The results are shown in table 5. As seen, the relationship between attitudes on advertising with variables of all hypotheses is significant in confidence level as $99 \%$. Concerning the significance between the variables of research hypotheses, we test them: 
Table 5. the Relationship Between the Variables of Hypotheses

\begin{tabular}{llrl}
\hline \multicolumn{1}{c}{ Indices } & $\begin{array}{r}\text { Correlation } \\
\text { Relation }\end{array}$ & Test result \\
\hline 1. Accessibility and Satisfaction & & & \\
2. Easiness and Satisfaction & 0.328 & 0.001 & Significant relationship confirmed \\
3. Trust and Satisfaction & 0.332 & 0.003 & Significant relationship confirmed \\
4. Security and Satisfaction & 0.156 & 0.000 & Significant relationship confirmed \\
5. Website Designing and & 0.421 & 0.000 & Significant relationship confirmed \\
Satisfaction & 0.243 & 0.009 & Significant relationship confirmed \\
6. Website Content and Satisfaction & & & \\
7. Speed and Satisfaction & 0.314 & 0.005 & Significant relationship confirmed \\
8. Commission and Satisfaction & 0.567 & 0.000 & Significant relationship confirmed \\
9. Satisfaction and Brand Equity & -0.243 & -0.006 & Significant relationship confirmed \\
\hline
\end{tabular}

The results of testing research hypotheses based on SEM are shown in table 6. As seen, based on t statistic, all hypotheses are supported. Hypotheses 1, 2, 3, 4 and 7 in confidence level as 99\% and hypotheses 5, 6 and 8 in confidence level as $95 \%$ are supported. So, one can conclude that variables like "Accessibility", "Easiness", "Trust", "Security" and "Speed" in 99\% confidence level and "Website designing", "Website content" and "Commission" in 95\% confidence level impact significantly on "Satisfaction". In the meantime, "Satisfaction" on "Brand Equity" in 99\% confidence level.

According to path ratios, one can conclude that the impact of such variables as "Accessibility", "Easiness", "Trust", "Security", "Website designing", "Website content" and "Speed" on "Satisfaction" and the impact of "Satisfaction" on Brand Equity is linear, positive and straightforward; that is, one percent improvement in "Accessibility", it is $99 \%$ possible that "Satisfaction" will increase $45 \%$. The impact of "Commission" on "Satisfaction" is linear, negative and indirect; that is, decrease in dependent variable improves "Satisfaction" and vice versa. The ratios of other hypotheses can be described similarly.

The amount of determined ratio regarding the impact of all independent variables on Satisfaction is 0.71 . It shows that independent variables "Accessibility", "Easiness", "Trust", "Security", "Website designing", "Website content", "Speed" and "Commission" can forecast $71 \%$ of changes in Satisfaction and remained $29 \%$ is due to forecasting error and it can include other influencing variables over Satisfaction.

The amount of determined ratio regarding the impact of Satisfaction on Brand Equity is 0.56. It shows that Satisfaction can forecast $56 \%$ of changes in Brand Equity and remained $44 \%$ is due to forecasting error and it can include other influencing variables over Brand Equity.

Table 6. Testing Research Hypotheses

\begin{tabular}{lllll}
\hline \multicolumn{1}{c}{ Indices } & $\mathrm{t}$ & $(\beta)$ & $\left(\mathrm{r}^{2}\right)$ & Result \\
\hline Hypothesis & & $3.32^{* *}$ & 0.45 & Confirmed \\
1. The Impact of Accessibility on Satisfaction & $3.89^{* *}$ & 0.26 & Confirmed \\
3. The Impact of Easiness On Satisfaction & $2.98^{* *}$ & 0.14 & Confirmed \\
4. The Impact of Security on Satisfaction & $5.67^{* *}$ & 0.37 & Confirmed \\
5. The Impact of Website Designing on Satisfaction & $2.22^{*}$ & 0.18 & Confirmed \\
6. The Impact of Website Content on Satisfaction & $2.28^{*}$ & 0.11 & Confirmed \\
7. The Impact of Speed on Satisfaction & $5.94^{* *}$ & 0.58 & 0.71 Confirmed \\
8. The Impact of Commission on Satisfaction & $-2.01^{*}$ & -0.13 & & Confirmed \\
& & & & \\
9. The Impact of Satisfaction on Brand Equity & $4.18^{* *}$ & 0.52 & 0.56 Confirmed
\end{tabular}

*Significant in confidence level as $95 \%$

** Significant in confidence level as 99\% 


\section{Discussion and conclusion}

In present study, the most important e-baking service quality Dimensions are initially investigated and identified to achieve customers' satisfaction and improve Brand Equity from Refah Bank internet services and then affecting factors on customers' satisfaction were recognized. After studying the literature, such factors as "Accessibility", "Easiness", "Trust", "Security", "Website designing", "Website content", "Speed" and "Commission" were investigated and then their impacts on customers' satisfaction and Brand Equity were measured. The results of gathered data analysis show that "Accessibility", "Easiness", "Trust", "Security", "Website designing", "Website content", "Speed" and "Commission" significantly on Satisfaction. The impact of "Accessibility", "Easiness", "Trust", "Security", "Website designing", "Website content" and "Speed" is positive and the impact of "Commission" is negative. Further, the results show that the impact of "Satisfaction" on Brand Equity is significant. On this basis, one can conclude that by improving accessibility and easiness, making websites more user-friend, promoting the security and speed, paying attention to design and content of websites, mitigating the commissions and building trust among customers, one can fascinate their satisfaction and improve profitability and Brand Equity.

\section{Recommendations}

Concerning the competitiveness of banking system and plans like respect to the client, it is highly important to value the customer and give the rights to him/her. To this end, following recommendations are represented:

1) There should be periodical polling to measure the quality of services and the satisfaction of customers, to be aware of their demands and expectations and to take steps toward their requests.

2) Employing specialized and professional forces in software, hardware and network fields in order to remove any possible problem in the system rapidly to prevent customers waiting too long to receive the services.

3) Valuing customers' time and mitigating their waiting time in receiving internet banking services

4) Paying attention to the beauty and desired designing on the website

5) Communicating information on the rules and commitments of the bank

6) Establishing an active and updated unit to respond complaints against internet banking system.

7) Concerning the last year event in which some codes of ATM systems were revealed as well as a gap between desired mode and the current satisfaction feeling of customers toward the security of their personal data, it is necessary that banks enhance their software groups and move toward a direction where the possibility of penetrating into their website are minimized and customers' trusts are increased.

8) Concerning the important issue of advertising, banks should clarify proper advertising strategies to persuade their customers to use online banking services more. Culture building on internet banking demands that banks try to expand online banking culture though their researches and to transfer their internet banking knowledge and its advantages to people in order to build internet banking as a culture.

\section{References}

A.C.R. Van Riel, V. Liljander, P. Jurriens, Exploring consumer evaluations of e-services: a portal site, International Journal of Service Industry Management 12 (4), 2001, pp.359-377. http://dx.doi.org/10.1108/09564230110405280

A.R. Hendrickson, M.R. Collins, An assessment of structure and causation of IS usage, The Database for Advances in Information Systems 27 (2), 1996, pp. 61-67. http://dx.doi.org/10.1145/243350.243361

Aaker, D. A. \& Bruzzone, D. E. (1981). Viewer Perceptions of Prime-Time Television Advertising. Journal of Advertising Research, 21(5), PP. 15-23.

Aaker, D. A. (1991). Managing Brand Equity, Capitalizing on the Value of Brand Name, New York: the Free Press.

Aaker, D.A., Bruzzone, D.E. (1985). "Causes of Irritation in Advertising” Journal of Marketing. Chicago. Vol. 49, Iss. 2; P. 47. http://dx.doi.org/10.2307/1251564

Aaker, D.A., Kumar, V., \& Day, G.S. (2001). Marketing Research, 7th. John Wiley Operations Research \& Sons, New York 51(4), 509-518.

Aladwani, A. M., \& Palvia, P. C. (2002). Developing and validating an instrument for measuring user-perceived web quality. Information \& Management, 39(6), 467-476. http://dx.doi.org/10.1016/S0378-7206(01)00113-6

Amoah-Mensah, Aborampah. (2010). Customer satisfaction in the banking industry: a comparative study of Ghana and spain(Doctoral dissertation). Retrieved from ProQuest Dissertation and Theses database. 
Arasli. H, Mehtap. S. S \& Turan. K. S. (2005). Customer service quality in the Greek Cypriot banking industry, Managing service quality, Vol.15 No.1, (2005), 41-56. http://dx.doi.org/10.1108/09604520510575254

Bloemer, J. M. M., \& Kasper, H. D. P. (1995). The Complex Relationship between Consumer Satisfaction and Brand Loyalty. Journal of Economic Psychology, 16 (2),311-29. http://dx.doi.org/10.1016/0167-4870(95)00007-B

Brian. J. C, Theerasak. T, Han. Y. (2003). Trust and e-commerce: a study of consumer perceptions, Electronic Commerce Research and Applications 2, (2003), 203-215. http://dx.doi.org/10.1016/S1567-4223(03)00024-3

Buil, I., Chernatony, L. D. \& Martinez, E. (2011). Examining the Role of Advertising and Sales Promotions in Brand Equity Creation, Journal of Business Research, 195-215.

C. Liu, K.P. Arnett, Exploring the factors associated with Web site success in the context of electronic commerce, Information \& Management 38, 2000, pp. 23-34. http://dx.doi.org/10.1016/S0378-7206(00)00049-5

C.S. Lin, S. Wu. (2002). Exploring the impact of online service quality on portal site usage, in: Proceedings of the 35th Hawaii International Conference on System Science. http://dx.doi.org/10.1109/HICSS.2002.994223

Carlos. F, Miguel, G, Raquel. G. (2006). The role played by perceived usability, satisfaction and consumer trust on website loyalty, Information \& Management 43, (2006), 1-14. http://dx.doi.org/10.1016/j.im.2005.01.002

Chaudhuri, A. \& Holbrook B. M. (2001). The Chain of Effects From Brand Trust and Brand Affects to Brand Performance: the Role of Brand Loyalty, Journal of Marketing, 65, PP. 81-93.

DeLone, W. H., \& McLean, E. R. (1992). Information system success: The quest for the dependent variable. Information Systems Research, 3(1), 60-95. http://dx.doi.org/10.1287/isre.3.1.60

E.T., Loiacono, R.T. Watson, D.L. Goodhue. (2002). WebQual: a measure of Website quality, 2002 Marketing Educators' Conference: Marketing Theory and Applications, vol. 13, 2002, pp. 432-437.

Ehigie, B. O., \& Taylor, M. (2009). Managing student's loyalty to school after graduation through relationship marketing. The TQM Journal. 21(5), 502-516. http://dx.doi.org/10.1108/17542730910983416

Farquhar, Jillian Dawes, Panther, Tracy. (2008). Acquiring and retaining customers in UK banks: An exploratory study Journal of retailing and customer services, 15, 9-21.

Fornell, C., \& Larcker, D. F. (1981). Evaluating Structural Equation Models With Unobservable Variables And Measurement Error. Journal Of Marketing Research, 18(Feb.), Pp. 39-50. http://dx.doi.org/10.2307/3151312

Friman, Margareta, Edvardsson, Bo. (2003). "A content analysis of complaints and compliments", Managing Service Quality, 13(1), 20 - 26. http://dx.doi.org/10.1108/09604520310456681

Gerlach, D. (2000). Put your money where your mouse is. PC World, .March, 191-9.

Gerrard, P., \& Cunningham, J. (2003). The diffusion of internet banking among Singapore consumers". International Journal of Bank Marketing, 21, (1), pp.16-28. http://dx.doi.org/10.1108/02652320310457776

Gu, J.C., Lee, S.C., Suh, Y. H. (2009). Determinants of behavioral intention to mobile banking, Expert Systems with Applications, 36, 11605-11616. http://dx.doi.org/10.1016/j.eswa.2009.03.024

Gupta, S. \& Zeithaml, V. (2006). Customer metrics and their impact on financial performance ee Marketing Science, 25 (6), 718-39. http://dx.doi.org/10.1287/mksc.1060.0221

Hackett, S \& Parmanto, B. (2009). "Homepage not enough when evaluating web site accessibility". Internet Research, 19, (1),pp.78 - 87. http://dx.doi.org/10.1108/10662240910927830

Han.S.L, Baek.S. (2004). "Antecedents and Consequences of Service Quality in Online Banking: An Application of the SERVQUAL Instrument", Advances in Consumer Research, Vol. 31, PP. 208-214.

He, H. Li, Y. \& Harris, L. (2011). Social Identity Perspective on Brand Loyalty. Journal of Business Research, 65(5), PP. 648-657.

Jamal, Ahmad, Naser, Kamal. (2002). "Customer satisfaction and retail banking: an assessment of some of the key antecedents of customer satisfaction in retail banking", International Journal of Bank Marketing, 20(4), 146 160. http://dx.doi.org/10.1108/02652320210432936

Jiyoung. K, Byoungho. J, Jane. L. S. (2009). The role of retail quality, e-satisfaction and e-trust in online loyalty development process, Journal of Retailing and Consumer Services 16, (2009), 239-247. http://dx.doi.org/10.1016/j.jretconser.2008.11.019 
Jun, M., \& Cai, S. (2001). The key determinants of Internet banking service quality: A content analysis. The International Journal of Bank Marketing, 19(7), 276-291. http://dx.doi.org/10.1108/02652320110409825

Jun, M., \& Cai, S. (2001). The key determinants of internet banking service quality: a content analysis. International Journal of Bank Marketing, 19, (7), 276-91. http://dx.doi.org/10.1108/02652320110409825

K.V. La, J. Kandampully. (2002). Electronic retailing and distribution of services: cyber intermediaries that serve customers and service providers, Managing Service Quality 12 (2), 2002, pp. 100-116. http://dx.doi.org/10.1108/09604520210421400

Kassim, N.M. (2009). "Consumers' behavior and their perceptions of quality of life: does culture matters?", Proceedings of the Pan-Pacific Conference XXVI, Shenzhen, June 1-3, pp. 260-262.

Khan.M.S, Mahapatra.S.S, Sreekumar. (2009). "Service quality evaluation in internet banking: an empirical study in India", Int. J. Indian Culture and Business Management, Vol. 2, No. 1, PP. 30-46.

Lee Kun Chang, Chung Namho. (2009). "Understanding factors affecting trust in and satisfaction with mobile banking in Korea: A modified DeLone and McLean's model perspective", Interacting with Computers, Volume 21, Issues 5-6, December 2009, Pages 385-392.

Lee.T.C. (2009). "Factors Influencing the Adoption of Internet Banking: An Integration of TAM and TPB with Perceived Risk and Perceived Benefit", Electronic Commerce Research and Applications, Vol. 8, PP. 130-141.

Liao, Z., \& Cheung, M. T. (2002). Internet-based e-banking and consumer attitudes: An empirical study. Information \& Management, 39(4), 283-295. http://dx.doi.org/10.1016/S0378-7206(01)00097-0

Liao, Z., \& Cheung, M. T. (2008). Measuring consumer satisfaction in Internet banking: a core framework. Communications of the ACM, 51(4), 47-51. http://dx.doi.org/10.1145/1330311.1330322

Liu, X., He, M., Gao, F., \& Xie, P. (2008). An empirical study of online shopping customer satisfaction in China: A holistic perspective. International Journal of Retail \& Distribution Management, 36(11), 919-940. http://dx.doi.org/10.1108/09590550810911683

Luis V. C, Carlos. F and Miguel. G. (2008). The role of satisfaction and website usability in developing customer loyalty and positive word-of-mouth in the e-banking services, Vol. 26 No. 6, (2008), 399-417.

M.M. Misic, K.L. Johnson. (1999). Benchmarking: a tool for Web site evaluation and improvement, Internet Research: Electronic Networking Applications and Policy 9 (5), 1999, pp. 383-392. http://dx.doi.org/10.1108/10662249910297787

Ma, Zhengwei. (2012). Factors Affect the Customer Satisfaction of Internet Banking: An Empirical Study in China. Journal of Convergence Information Technology, Vol. 7 (3), 101-109. http://dx.doi.org/10.4156/jcit.vol7.issue3.12

Martínez, E. Montaner, E. \& Pina, J. M. (2009). Brand Extension Feedback: the Role of Advertising, Journal of Business Research, 62(3), PP. 305-313.

Mohd Khalaf Ahmad, Ala Eddin. Ali Al-Zu'bi, Hasan. (2011). E-banking Functionality and Outcomes of Customer Satisfaction: An Empirical Investigation, International Journal of Marketing Studies, Vol. 3, No. 1.

N. Cho, S. Park. (2001). Development of electronic commerce user consumer satisfaction index (ECUSI) for internet shopping, Industrial Management \& Data Systems 101 (8), 2001, pp. 400-405.

Oliver, R.L. (1999). Whence consumer loyalty? Journal of Marketing 63, 33-44. http://dx.doi.org/10.2307/1252099

Palmer, J. W. (2002). Web site usability, design, and performance metrics. Information Systems Research, 13(2), 151-167. http://dx.doi.org/10.1287/isre.13.2.151.88

Petridou, Eugenia, Spathis, Charalambos, Glaveli, Niki, Liassides, Chris. (2007). "Bank service quality: empirical evidence from Greek and Bulgarian retail customers", International Journal of Quality \& Reliability Management, 24(6), 568 - 585. http://dx.doi.org/10.1108/02656710710757772

Pratten , J.D. (2004). "Customer satisfaction and waiting staff", International of contemporary Hospitality management, Vol.16 No.6, pp.385-388.

Ranganathan, C., \& Ganapathy, S. (2002). Key dimensions of business to consumer web sites. Information \& Management, 39(6), 457-465. http://dx.doi.org/10.1016/S0378-7206(01)00112-4

Reichheld, F.F. \& Schefter, P. (2000). E-loyalty: your secret weapon on the web, Harvard Business Review, Vol. 78 No. 4, (2000), 105-114. 
Rod, M., Ashill, N. J., Shao, J., \& Carruthers, J. (2009). An examination of the relationship between service quality dimensions, overall internet banking service quality and customer satisfaction: A New Zealand study. Marketing Intelligence \& Planning, 27(1), 103-126. http://dx.doi.org/10.1108/02634500910928344

Siriluck, R., \& Speece, M. (2003). Barriers to internet banking adoption: a qualitative study among corporative customers in Thailand. International Journal of Bank Marketing, 21, (6), 312-23.

Srini S. Srinivasan, Rolph Anderson, Kishore Ponnavolu. (2002). Customer loyalty in e-commerce: an exploration of its antecedents and consequences, Journal of Retailing 78, (2002), 41-50. http://dx.doi.org/10.1016/S0022-4359(01)00065-3

Srinivasan, A. (1985). Alternative measures of system effectiveness: Associations and implications. MIS Quarterly, 9(3), 243-253. http://dx.doi.org/10.2307/248951

Suh, B., \& Han, I. (2003). The impact of customer trust and perception of security control on the acceptance of electronic commerce. International Journal of Electronic Commerce, 7(3), 135-166.

Swaid.S.I, Wigand.R.T. (2007). "Key Dimensions of E-commerce Service Quality and Its Relationships to Satisfaction and Loyalty", 20th Bled e Conference, eMergence: Merging and Emerging Technologies, Processes and Institutions; Bled, Slovenia.

Tan,K.C. \& Pawitra,T.A. (2001). Integrating Servqual and Kano's model into QFD for Service Excellence Development, Managing Service Quality, 11(6),418-430. http://dx.doi.org/10.1108/EUM000000006520

Vainio, M.M. (2006). Factor influencing customers' acceptance of internet banking: case of Scandinavian trade finance customers, M.Sc. Thesis in accounting, The Swedish School of economics \& business administration.

Wang, Y.S., Wang, Y.M., Lin, H.H. \& Tang, T.I. (2003). "Determinants of user acceptance of internet banking: an empirical research", International Journal of Bank Marketing, Vol. 14 No. 5, pp. 501-19.

White, H., Nteli, F. (2004). "Internet banking in the UK: why are there not more customers?" Journal of Financial Services Marketing, Vol. 9 pp.49-57. http://dx.doi.org/10.1057/palgrave.fsm.4770140

Wirtz. J, \& Chew, P. (2002). The Effects of Incentives, Deal proneness, Satisfaction and Tie strength on word of Mouth Behavior, International Journal of service Industry Management, Vol. 13 No. 2. (2002).

Xu ,Q., J. Roger, X. Yang \& M. G. Helander. (2009). "An Analytical Kano Model for Customer Need Analysis," Design Studies, 30(1), 87-110. http://dx.doi.org/10.1016/j.destud.2008.07.001

Yanga.Z, Caib.S, Zhouc.Z, Zhoua.N. (2005). "Development and validation of An Instrument to Measure User Perceived Service Quality of Information Presenting Web Portals", Information \& Management, Vol. 42, PP $575-589$.

Yoo, B., Donthu, N. \& Lee, S. (2000). An Examination of Selected Marketing Mix Elements and Brand Equity, Journal of the Academy of Marketing Science, 28(2), PP. 195-211.

Yoon, C., \& Kim, S. (2009). Developing the causal model of online store success. Journal of Organizational Computing and Electronic Commerce, 19(4), 265-284. http://dx.doi.org/10.1080/10919390903262644

Yoon.Ch. (2010). "Antecedents of Customer Satisfaction with Online Banking in China: The Effects of Experience", Computers in Human Behavior, Vol. 26, PP 1296-1304.

Yousafzai, Sh., Yani-de-Soriano, M. (2012). Understanding customer-specific factors underpinning internet banking adoption, International Journal of Bank Marketing, Vol. 30 No. 1, 60-81. http://dx.doi.org/10.1108/02652321211195703

Yuksel, Atila, Yuksel, Fisun ,Bilim ,yasin. (2010). Destination attachment: Effects on customer satisfaction and cognitive, affective and cognitive loyalty, journal of tourism management 31, 274-284.

Zhilin Yang., Shaohan Cai., Zheng Zhou., Nan Zhou. (2004). Development and validation of an instrument to measure user perceived service quality of information presenting Web portals, Information \& Management 42 (2005) 575-589.

Zviran, M., Glezer, C., \& Avni, I. (2006). User satisfaction from commercial web sites: The effect of design and use. Information \& Management, 43(2), 157-178. http://dx.doi.org/10.1016/j.im.2005.04.002 